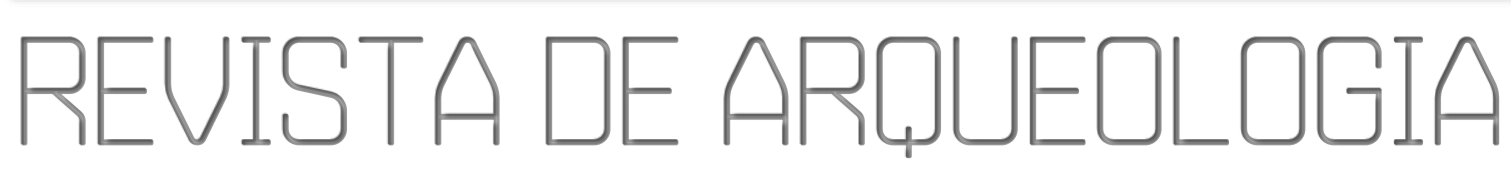

Volume 33 No.1 $2020 \quad$ Edição Especial: Museu Nacional [Volume 2]

\title{
RITUAL FUNERÁRIO NO SAMBAQUI DE AMOURINS [GUAPIMIRIM/RJ]:
}

ATIVIDADES DE PREPARAÇÃO DO TERRENO PARA RECEBER O CORPO

Ana Luiza Berredo*, Maria Dulce Gaspar*, Renato Rodriguez Cabral Ramos ${ }^{* * *}$,

Gina Faraco Bianchini ${ }^{* \star * *}$

RESUMO

$\mathrm{O}$ artigo sintetiza os resultados da escavação de dois blocos-testemunhos com sepultamentos resgatados do sambaqui de Amourins, sítio datado em cerca de 4000 anos AP. O sedimento disposto abaixo dos ossos humanos foi descrito e analisado, com objetivo de investigar as atividades rituais que antecedem a deposição do morto. Os resultados demonstraram uma sequência estratigráfica intencionalmente construída para formatação da cena fúnebre, indicando que muito provavelmente havia escolha de materiais específicos para as diferentes partes dos corpos.

Palavras-chave: Estratigrafia; Sepultamentos; Cena Fúnebre.

* Universidade Federal do Rio de Janeiro, Museu Nacional. Departamento de Arqueologia. E-mail: analuizaberredo@hotmail.com. ORCID: https://orcid.org/0000-0002-6924-747X.

** Universidade Federal do Rio de Janeiro, Museu Nacional. Departamento de Arqueologia. E-mail: madugasparmd@gmail.com. ORCID: https://orcid.org/0000-0002-5483-4495.

*** Universidade Federal do Rio de Janeiro, Museu Nacional, Departamento de Geologia e Paleontologia. E-mail: rramos@mn.ufrj.br. ORCID: https://orcid.org/0000-0003-4023-6301.

**** Artefato: Arqueologia e Patrimônio. E-mail: ginabianchini@hotmail.com.

ORCID: https://orcid.org/0000-0002-7991-976X. 


\section{FUNERAL RITUAL IN THE SHELLMOUND AMOURINS [GUAPIMIRIM/RJ): PREPARATORY ACTIVITIES OF THE GROUND TO RECEIVE THE BODY}

\section{ABSTRACT}

The article summarizes the results of Berredo's research (2018) that excaved two testimony blocks with burials rescued from the Amourins shellmound, a site dated around 4000 years AP. The sediment disposed below the human bones was described and analyzed, in order to investigate the ritual activities that precede the deposition of the deceased. The results showed a stratigraphic sequence intentionally constructed to format the funeral scene, indicating that, most likely, there was a choice of specific materials for the different parts of the bodies.

Keywords: Stratigraphy; Burials; Funeral scenery.

\section{RITUAL FUNERARIO EN EL SHELLMOUND AMOURINS [GUAPIMIRIM/RJ): ACTIVIDADES DE PREPARACIÓN DEL TERRENO PARA RECIBIR EL CUERPO}

\section{RESUMEN}

El artículo resume los resultados del estudio de Berredo (2018) que excavó dos bloques de testimonios con entierros rescatados del Amourins sambaqui, un sitio que data de alrededor de 4000 años AP. El sedimento dispuesto debajo de los huesos humanos fue descrito y analizado, con el fin de investigar las actividades rituales que preceden a la deposición del difunto. Los resultados mostraron una secuencia estratigráfica construida intencionalmente para formatear la escena del funeral, lo que indica que, muy probablemente, había una selección de materiales específicos para las diferentes partes de los cuerpos.

Palabras clave: Estratigrafía; Enterro; Cena Funeraria. 


\section{INTRODUÇÃO}

Sambaquis são construções monticulares intencionalmente construídas, e muitos deles têm relação estreita com a recorrência de práticas funerárias (FISH et al., 2000; DEBLASIS et al., 2007; GASPAR et al., 2013, PLENS, 2007; SILVA, 2005; KLOKLER, 2012).

No entorno da Baía de Guanabara/RJ, testemunhos de rituais funerários já foram identificados e estudados em numerosas pesquisas (MELLO \& SOUZA, 1977; BELTRÃO, 1978; HEREDIA \& BELTRÃO, 1980; BELTRÃO et al., 1982; HEREDIA et al., 1982; MENDONÇA DE SOUZA \& MENDONÇA DE SOUZA, 1983; GASPAR, 1991; PAZ, 1999; GASPAR et al., 2013; CARDOSO, 2013; BIANCHINI, 2015; ESTANEK, 2016; BERREDO, 2018; SOUZA-PINTO, 2018; ÁVILA, 2018). Através de diferentes abordagens, foram revelados dados importantes sobre as práticas funerárias, demonstrando que a pesquisa dos ritos fúnebres tem a capacidade não apenas de elucidar sobre a organização social, mas também sobre as visões de mundo e crenças que auxiliam na investigação dos comportamentos e das práticas sociais envolvidas nas concepções sobre a morte (PEARSON, 2002; BELL,1997).

Os recentes trabalhos desenvolvidos nos sambaquis de Amourins e Sernambetiba, no município de Guapimirim (RJ), revelaram aspectos importantes do programa funerário desses sítios que permitem afirmar que o corpo ocupava lugar de destaque entre os sambaquieiros (KLOKLER \& GASPAR, 2013: 112; GASPAR et al., 2013; CARDOSO, 2013; ÁVILA, 2018; SOUZA-PINTO, 2018). As evidências indicam o cuidado com o corpo, mostrando ossos humanos com marcas de corte, em especial os ossos longos (ESTANEK, 2016), além disso também foram visualizadas estruturas de visitação próximas aos locais de sepultamento (BIANCHINI, 2015), destacados lugares de sepultamento (BERREDO, 2018) e acompanhamentos funerários como receptáculo de conchas e ossos de peixes (SOUZA et al., 2012; KLOKLER \& GASPAR, 2013).

A partir dessas pesquisas, considerou-se que o local de deposição dos corpos também receberia certa atenção. Conforme já evidenciado nas análises estratigráficas do sambaqui como Jabuticabeira II e Sernambetiba (VILLAGRAN, 2010; BIANCHINI, 2015), é pouco provável que os corpos fossem depositados na superfície imediata do sítio, sem que houvesse algum tipo de preparo, cabendo a esta pesquisa investigar de que forma foi feita a preparação do terreno pra receber o corpo.

Diante disso, foram estudados dois blocos-testemunhos resgatados do sambaqui de Amourins, através da descrição e análise do contexto estratigráfico, com a finalidade de compreender o programa funerário.

A análise dos sepultamentos resgatados a partir da técnica de retirada em blocos é pertinente para o estudo das atividades iniciais que englobam a criação do espaço ritual, permitindo detalhar as atividades preparatórias que compõe a cena fúnebre (KLOKLER \& GASPAR, 2013). De acordo com Souza \& Rodrigues-Carvalho (2013b: 556), essa estratégia de pesquisa proporciona tempo e condições necessárias para a escavação em laboratório, permitindo visualizar os processos pós-deposicionais tafonômicos e identificar possíveis agentes de transformação, fatores que se tornam ainda mais importantes quando são decorrentes de ações antrópicas.

Através das escavações em laboratório, foi possível analisar e registrar de forma detalhada a sucessão das camadas localizadas imediatamente abaixo dos esqueletos, uma vez que a caracterização da estratigrafia de um sítio é uma etapa fundamental para a interpretação das variações verticais e laterais dos depósitos arqueológicos e do seu significado arquitetônico.

Apoiando-nos nas reflexões de Villagran (2010: 54) e Ramos et al. (2013), foi realizada a análise de fácies arqueológicas dos blocos-testemunhos, seguida da 
interpretação das atividades construtivas. Os resultados obtidos demonstraram que a disposição e organização dos materiais empreendidos na construção do local dos sepultamentos são intencionais e tem relação com as práticas funerárias, sugerindo que havia tratamento diferenciado no preparo do terreno construído para receber as diferentes partes do corpo.

\section{O SAMBAQUI DE AMOURINS}

Amourins está localizado no município de Guapimirim, estado do Rio de Janeiro, na margem esquerda do Rio Guapimirim, na fazenda Santa Rita de Cássia, a $5 \mathrm{~km}$ da baía de Guanabara. Possui $60 \mathrm{~m}$ de comprimento, $10 \mathrm{~m}$ de largura, $2,80 \mathrm{~m}$ de altura e volume atual estimado de $1700 \mathrm{~m} 3$. Suas camadas são compostas principalmente por conchas de Anomalocardia brasiliana, Lucina pectinata, ostras e ossos de peixe. Também foram recuperados diversos artefatos em ossos de fauna, distribuídos ao longo dos níveis de escavação (HEREDIA \& BELTRÃO, 1980; BELTRÃO et al., 1981/1982; HEREDIA et al., 1982; GASPAR et al., 2013) (Figura 1).

Figura 1 - Sambaqui de Amourins - Seção 30-35m antes da retirada dos sepultamentos (imagem de 2010).

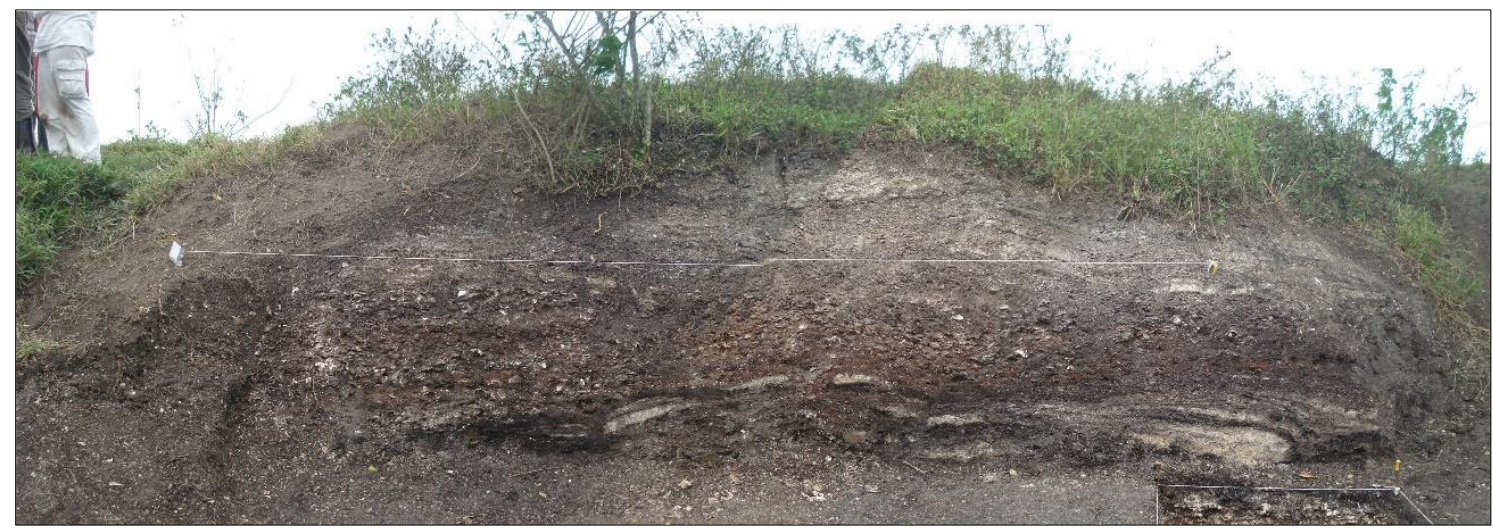

$\mathrm{Na}$ década de 1970, Osvaldo Heredia, professor do Museu Nacional, foi coordenador das primeiras pesquisas no sambaqui de Amourins (GASPAR et al., 2013: 11). As escavações revelaram a presença de dois esqueletos, cujos ossos foram escavados, analisados e posteriormente armazenados na reserva técnica do Museu Nacional (HEREDIA et al., 1982).

Em 2010, os estudos no sítio foram retomados ${ }^{1}$ com o objetivo de entender as atividades relacionadas ao processo de construção dos sambaquis (GASPAR et al., 2013: 13). Durante essa etapa, foram recuperados três esqueletos (A, B e C), totalizando em cinco o número de esqueletos resgatados desde as primeiras escavações.

O presente estudo, parte da dissertação de Berredo (2018), apresenta os resultados obtidos a partir da análise dos esqueletos $\mathrm{A}$ e $\mathrm{C}$, cujos blocos ofereceram excelente oportunidade para um estudo minucioso. Ambos foram identificados a aproximadamente $1,30 \mathrm{~m}$ de profundidade em relação à superfície atual do sambaqui, durante abertura de uma coluna de 2,00m x 0,50m, na seção $30-35 \mathrm{~m}$, para a coleta de amostras para análise zooantracológica (GASPAR et al., 2013: 15).

\footnotetext{
${ }^{1}$ Projeto "Sambaquis médios, grandes e monumentais: estudo sobre as dimensões dos sítios arqueológicos e seu significado social”, coordenado por Maria Dulce Gaspar e apoiado pela FAPERJ/PRONEX (Processo E-26/110.569/2010).
} 
Foram retirados nas etapas de campo de 2011 e 2012, sob a supervisão dos pesquisadores Sheila Mendonça de Sousa e Andersen Liryo, e levados para o Laboratório de Arqueologia Casa de Pedra no Museu Nacional (SOUZA et al., 2012). Dessa maneira, a análise dos sepultamentos A e $\mathrm{C}$ teve como referência a pesquisa de Souza et al. (SOUZA et al., 2012), que revelou informações importantes sobre os esqueletos e também sobre a estratigrafia associada os corpos. As reflexões dos autores foram ponto de partida para a investigação em laboratório.

\section{ATIVIDADES DE PREPARAÇÃO DOS TERRENOS: DESCRIÇÃO ESTRATIGRÁFICA E ANÁLISE DOS MATERIAIS}

O modo de escavação desenvolvido nessa pesquisa seguiu a linha de trabalho empregada por Souza e Rodrigues-Carvalho (SOUZA \& RODRIGUES-CARVALHO, 2013) e Sousa et al. (2013), em que os autores ressaltam o importante papel da observação estratigráfica realizada desde o campo até o resgate em bloco e escavação em laboratório.

Nas escavações dos blocos de sepultamento em laboratório, foram observados aspectos como a construção da área funerária através da análise das fácies arqueológicas, de modo a estabelecer sua organização em sequência numérica seguida da alfabética correspondente ao sepultamento ao qual a fácies está vinculada (Ex: 1a, 2a...; 1c, 2c...).

Foram levantadas informações do material construtivo: tipo (areia, argila, mariscos, carvões, cinza), quantidade/volume, dimensão, repetição e disposição das fácies no bloco. Observou-se também a granulometria, a maleabilidade e a conservação dos materiais construtivos (preservados/friáveis/destruídos). Por último, as fácies foram nomeadas de acordo com a sucessão estratigráfica que corresponde às atividades empreendidas na construção do ritual fúnebre. Todas essas observações foram realizadas para compreensão do modo como o terreno foi preparado para receber o corpo.

Durante a escavação dos blocos, todos os materiais recuperados foram separados por tipo (osso humano, lítico, fauna, sedimento e amostras para análises específicas), identificados e numerados. A identificação no âmbito da ictiologia foi realizada pelos pesquisadores Mariana Lopes e Simon Pierre. O material foi acondicionado no Laboratório de Arqueologia Casa de Pedra, do Museu Nacional/UFRJ, onde foram realizadas diferentes análises e a curadoria.

Conforme metodologia aplicada por Estanek (2016), a escavação foi iniciada com a abertura dos blocos pelo topo, para exposição do esqueleto. Em seguida houve a retificação das seções, e a escavação foi feita por níveis naturais, seguindo as superfícies de acamamento e seus contatos.

O registro de todas as etapas de escavação foi feito por meio de fotografias panorâmicas das seções, anotações em cadernetas e desenhos dos perfis/seções arqueológicas. Para ajudar a observação minuciosa das fácies arqueológicas que compõem o bloco, foram utilizadas as técnicas da fotogrametria, adaptada por Magalhães et al. (2018), fotomosaico (RAMOS et al., 2013) e o desenho interpretativo.

O desenho do perfil estratigráfico foi feito, tanto em campo quanto em laboratório, diretamente no bloco, por meio da técnica de fotomosaicos cuja principal contribuição está associada ao fato de que ela dá destaque aos aspectos arquiteturais dos sambaquis (Figura 2). 
Figura 2 - Fotomosaico da sessão 30-35m onde foram encontrados os sepultamentos A e C (desenho: Renato Ramos).

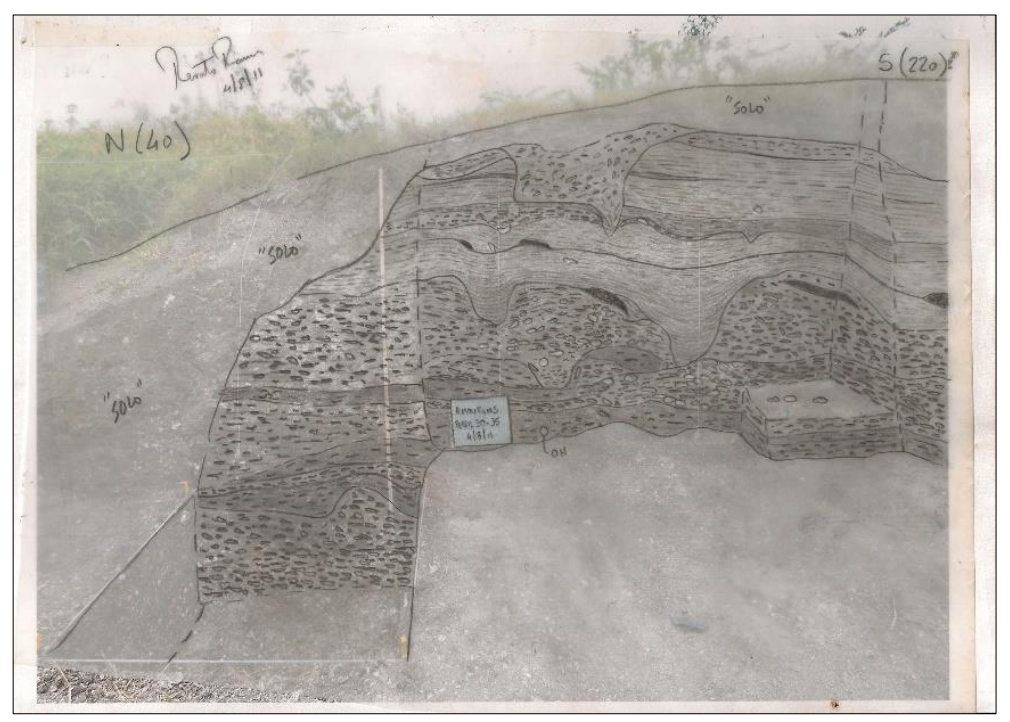

Na realização do fotomosaico do bloco, foram feitas as descrições dos componentes e análise das fácies. Para a descrição, foram considerados os seguintes critérios estabelecidos de acordo com métodos geológicos aplicados à arqueologia: composição; caracterização; espessura; matriz; granulometria/formato dos grãos; coloração (de acordo com Munsell - cartela de solos); e contato entre as superfícies de acamamento (irregular, erosivo, plano) (RAMOS et al., 2013).

Posteriormente à elaboração do fotomosaico e da identificação das fácies arqueológicas dos blocos, foram feitas a descrição e análise (Figura 3).

Figura 3 - a) Seção sudoeste do sepultamento A. b) Fotomosaico da seção sudoeste do sepultamento A. c) Seção Leste do bloco de sepultamento C, mostrando a disposição das fácies e a marca de estaca. d) Fotomosaico da seção Leste do Sepultamento C mostrando os contatos entre as fácies, evidenciando arquitetura do sambaqui. e) Seção Leste digitalizada, mostrando as seis fácies registradas no bloco. Destaca-se a marca de estaca na camada de cinzas e, no detalhe, uma possível evidência de outra marca de estaca (tracejada).

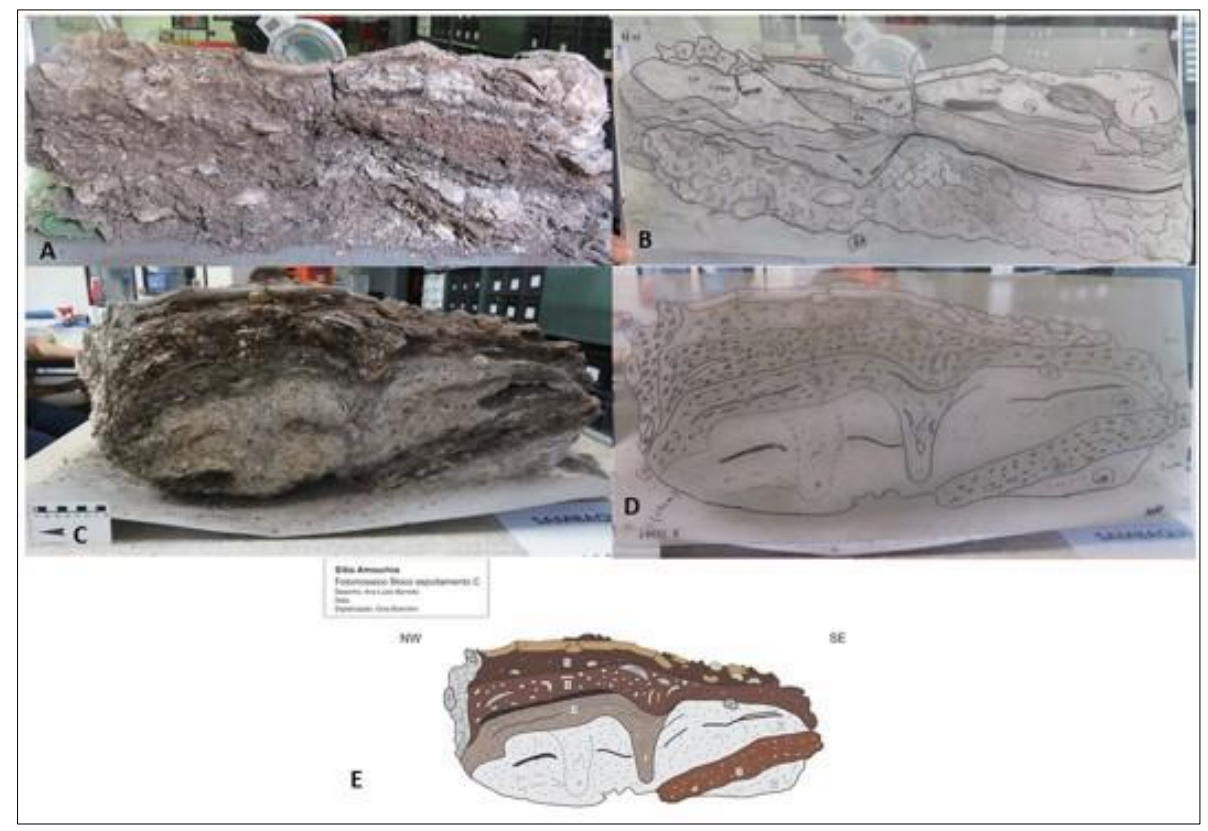


Os sedimentos foram separados e identificados de acordo com cada fácies e estão depositados na Reserva Técnica do Museu Nacional/UFRJ. Novos estudos, a partir de outras técnicas, poderão contribuir sobremaneira para a caracterização do ritual funerário do sambaqui de Amourins.

As análises estratigráficas realizadas nos blocos dos sepultamentos A e C revelaram os resultados abaixo.

Tabela 1 - Descrição e análise das fácies estratigráficas dos blocos-testemunhos.

\begin{tabular}{|c|c|c|c|}
\hline Sepultamento & Fácies & Descrição & Interpretação \\
\hline \multirow{5}{*}{ A } & $\begin{array}{c}\text { fácies } \\
1 \mathrm{a}\end{array}$ & $\begin{array}{l}\text { Composta por cerca de } 70 \% \text { de } \\
\text { ostras e } 25 \% \text { de Lucina pectinata, } \\
\text { além de muitos mariscos } \\
\text { triturados que concedem a esta } \\
\text { fácies acentuada coesão. Está } \\
\text { assentada sobre camada natural } \\
\text { lamosa, da qual se distingue } \\
\text { fortemente. }\end{array}$ & $\begin{array}{l}\text { Refere-se a uma divisão entre o meio físico } \\
\text { e o espaço construído. A escolha de ostras } \\
\text { grandes e robustas parece ter objetivo de } \\
\text { criar uma base sólida e segura para receber } \\
\text { e suportar o peso das deposições } \\
\text { subsequentes, garantindo uma superfície } \\
\text { mais seca do que o entorno do sítio. Deu } \\
\text { início a construção da etapa do ritual. }\end{array}$ \\
\hline & $\begin{array}{c}\text { fácies } \\
2 \mathrm{a}\end{array}$ & $\begin{array}{l}\text { Composta por ossos de peixe e } \\
\text { finas lentes de carvão, com } \\
\text { coloração alaranjada. Apresenta } \\
\text { estratificação interna, indicando } \\
\text { sucessivos eventos de deposição. }\end{array}$ & $\begin{array}{l}\text { Seleção de materiais mais frágeis e } \\
\text { dispostos de forma ordenada. } \\
\text { Destaca-se o contraste nítido entre as duas } \\
\text { fácies (1a e 2a), a primeira composta por } \\
\text { materiais duros e resistentes, e a segunda, } \\
\text { por materiais finos e frágeis, com indícios } \\
\text { do uso do fogo. }\end{array}$ \\
\hline & $\begin{array}{c}\text { fácies } \\
3 a\end{array}$ & $\begin{array}{l}\text { Constituída de cinzas } \\
\text { predominantemente, de } \\
\text { geometria lenticular, maciça, } \\
\text { relativamente compactada. Está } \\
\text { em contato direto com os ossos } \\
\text { humanos, especialmente úmeros } \\
\text { e fêmures. }\end{array}$ & $\begin{array}{l}\text { Cinzas provenientes de intensas fogueiras, } \\
\text { provavelmente realizadas em outro local, } \\
\text { uma vez que os materiais associados a fácies } \\
\text { não apresentaram traços ou coloração } \\
\text { decorrente de queima. As cinzas parecem } \\
\text { ter sido depositadas para receber o crânio e } \\
\text { parte dos braços, não sendo visualizadas na } \\
\text { parte central (costelas e vértebras), o que } \\
\text { indica tratamento diferenciado para as } \\
\text { partes do corpo. }\end{array}$ \\
\hline & $\begin{array}{c}\text { fácies } \\
4 a\end{array}$ & $\begin{array}{l}\text { Composta por sedimento de } \\
\text { coloração marrom escuro, } \\
\text { compactado, mariscos triturados } \\
\text { e valvas de Lucina pectinata. Duas } \\
\text { conchas desta espécie foram } \\
\text { encontradas contendo ossos de } \\
\text { peixes e outras conchas em seu } \\
\text { interior }\end{array}$ & $\begin{array}{l}\text { Corresponde ao sedimento colocado } \\
\text { abaixo da parte central do corpo, referente à } \\
\text { caixa torácica e coluna vertebral. São } \\
\text { materiais diferentes dos encontrados para } \\
\text { receber o crânio, pelve e braços, indicando } \\
\text { escolhas específicas que sugerem } \\
\text { tratamento mais cuidadoso com essa parte } \\
\text { que, quando viva, guarda os órgãos vitais. } \\
\text { As conchas de Lucina pectinata encontradas } \\
\text { com ossos de peixes e outras conchas de } \\
\text { mesma espécie em seu interior parecem ter } \\
\text { funcionado como acompanhamento } \\
\text { funerário, formando uma espécie de } \\
\text { receptáculo. }\end{array}$ \\
\hline & $\begin{array}{c}\text { fácies } \\
5 \mathrm{a}\end{array}$ & $\begin{array}{l}\text { Formada por onze conchas de } \\
\text { Lucina pectinata inteiras e } \\
\text { fechadas, com tamanhos que } \\
\text { variam entre } 5 \text { a } 7 \mathrm{~cm} \text { e uma } \\
\text { concha de Ostrea sp. de } 10 \mathrm{~cm} \text {, } \\
\text { apresentando alto grau de }\end{array}$ & $\begin{array}{l}\text { As conchas estavam ordenadas e } \\
\text { compactadas, aparentemente tendo sido } \\
\text { dispostas para também receber o crânio, } \\
\text { parte anatômica que talvez fosse } \\
\text { considerada importante para os } \\
\text { sambaquieiros. }\end{array}$ \\
\hline
\end{tabular}




\begin{tabular}{|c|c|c|c|}
\hline Sepultamento & Fácies & Descrição & Interpretação \\
\hline & & $\begin{array}{l}\text { compactação, dureza e } \\
\text { resistência. Todas estavam } \\
\text { dispostas na posição horizontal e } \\
\text { localizadas abaixo do crânio. }\end{array}$ & \\
\hline $\mathrm{C}$ & $\begin{array}{c}\text { fácies } \\
1 c\end{array}$ & $\begin{array}{l}\text { Composta por cinzas soltas, finas } \\
\text { e desagregadas, formando um } \\
\text { material friável e macio. } \\
\text { Apresentou } 15 \mathrm{~cm} \text { de espessura, } \\
\text { estava situada na direção do } \\
\text { tórax. É interrompida pela fácies } \\
2 \mathrm{c} .\end{array}$ & $\begin{array}{l}\text { As cinzas foram consideradas a base da } \\
\text { construção do lugar do sepultamento e } \\
\text { parecem ter sido utilizadas como marcador } \\
\text { do início do ritual. Devido suas } \\
\text { características morfológicas, aparentam } \\
\text { proveniência de fogueiras realizadas em } \\
\text { outro local, uma vez que os materiais } \\
\text { associados à fácies não apresentaram traços } \\
\text { ou coloração decorrente de queima. }\end{array}$ \\
\hline $\mathrm{C}$ & $\begin{array}{c}\text { fácies } \\
2 c\end{array}$ & $\begin{array}{l}\text { Composta predominantemente } \\
\text { por ossos de peixes pequenos } \\
\text { dispostos em uma discreta } \\
\text { estratificação horizontal, } \\
\text { acompanhados por valvas inteiras } \\
\text { de Lucina pectinata. A coloração } \\
\text { varia entre o alaranjado e marrom } \\
\text { escuro. } \\
\text { A quantidade de mariscos } \\
\text { triturados se sobrepunha às } \\
\text { valvas inteiras de Lucina pectinata, } \\
\text { proporcionando um baixo grau } \\
\text { de compactação do sedimento. }\end{array}$ & $\begin{array}{l}\text { Composta por ossos de peixes que parecem } \\
\text { ter sido especificamente selecionados. A alta } \\
\text { frequência de ossos diminutos e frágeis, } \\
\text { indica a preferência por peixes de pequeno } \\
\text { porte que foram dispostos formando uma } \\
\text { fina lente. Considerando a leveza dos ossos, } \\
\text { parecem formar uma fácies apropriada para } \\
\text { não afundar nas cinzas macias, dando } \\
\text { estabilidade à fácies subsequente. } \\
\text { Essa fácies interrompe a fácies 1c, } \\
\text { parecendo fazer parte de outro montículo } \\
\text { existente no lugar de deposição do morto. }\end{array}$ \\
\hline $\mathrm{C}$ & $\begin{array}{c}\text { fácies } \\
3 c\end{array}$ & $\begin{array}{l}\text { Predominam ossos de peixe, } \\
\text { mariscos triturados e carvões, } \\
\text { com matriz arenosa marrom } \\
\text { escura, apresenta estratificação } \\
\text { horizontal e baixa compactação. } \\
\text { Foram observadas marcas de } \\
\text { estaca cortando verticalmente as } \\
\text { fácies, tanto na seção leste quanto } \\
\text { na seção sul. No interior das } \\
\text { marcas de estaca havia elementos } \\
\text { provenientes principalmente } \\
\text { dessa fácies. Os materiais } \\
\text { evidenciados no interior das } \\
\text { marcas de estaca estavam } \\
\text { dispostos na posição vertical, } \\
\text { sendo encontrado um osso de } \\
\text { peixe de aproximadamente } 4 \mathrm{~cm} \text { e } \\
\text { valvas de Lucina pectinata, além da } \\
\text { presença de mariscos triturados. }\end{array}$ & $\begin{array}{l}\text { Formada com materiais de integridade } \\
\text { baixa, que estavam macerados e triturados } \\
\text { complementando a estabilidade. As marcas } \\
\text { de estacas de destacam na seção } \\
\text { estratigráfica do bloco, interrompendo a } \\
\text { duas fácies anteriores e evidenciando osso } \\
\text { de peixe e outros mariscos que foram } \\
\text { deslocados de suas fácies para o interior da } \\
\text { estaca, ficando disposto na posição vertical. }\end{array}$ \\
\hline $\mathrm{C}$ & $\begin{array}{c}\text { fácies } \\
4 c\end{array}$ & $\begin{array}{l}\text { Composta por cerca de } 70 \% \text { de } \\
\text { Lucina pectinata e poucas valvas de } \\
\text { Ostrea sp. Coloração marrom } \\
\text { clara, com alguns pontos brancos. } \\
\text { Estavam dispostas com a parte } \\
\text { convexa para cima, porém não } \\
\text { apresentaram uma distribuição } \\
\text { homogênea. }\end{array}$ & $\begin{array}{l}\text { A maior incidência de conchas de Lucina } \\
\text { pectinata, indica intencionalidade na escolha } \\
\text { dessa concha para a disposição nessa fácies. } \\
\text { Essa espécie de concha apresenta valvas } \\
\text { duras que forneceram estrutura e } \\
\text { resistência ao sedimento. Além disso, valvas } \\
\text { inteiras dispostas com a parte convexa para } \\
\text { cima, também foram visualizadas na } \\
\text { camada de cobertura dos esqueletos. }\end{array}$ \\
\hline
\end{tabular}




\begin{tabular}{|c|c|c|c|}
\hline Sepultamento & Fácies & Descrição & Interpretação \\
\hline $\mathrm{C}$ & $\begin{array}{c}\text { fácies } \\
5 \mathrm{c}\end{array}$ & $\begin{array}{l}\text { Composta por valvas inteiras de } \\
\text { Lucina pectinata, alguns mariscos } \\
\text { triturados e sedimento arenoso } \\
\text { de coloração marrom. O } \\
\text { sedimento marrom arenoso foi } \\
\text { registrado em maior volume } \\
\text { quando comparado à quantidade } \\
\text { de mariscos, dando à fácies um } \\
\text { aspecto de "terra fofa”. Faz } \\
\text { contato com os ossos humanos. } \\
\text { Algumas valvas de Lucina } \\
\text { pectinata estavam abaixo das } \\
\text { vértebras torácicas e das epífises } \\
\text { proximais dos úmeros. Não foi } \\
\text { possível evidenciar recorrências } \\
\text { na disposição das valvas, } \\
\text { relacionadas a outras partes do } \\
\text { esqueleto. Essa fácies tem uma } \\
\text { característica particular, pois foi } \\
\text { formada por todos os materiais } \\
\text { encontrados nas outras fácies } \\
\text { como: ossos de peixes, carvões, } \\
\text { mariscos triturados e valvas de } \\
\text { Lucina pectinata, sem que tenha } \\
\text { havido predominância notável de } \\
\text { algum destes elementos. }\end{array}$ & $\begin{array}{l}\text { Disposta de modo a receber ossos humanos. } \\
\text { O aspecto de "terra fofa", sugere intenção de } \\
\text { formar lugar mais macio para colocação do } \\
\text { corpo. } \\
\text { A disposição das conchas abaixo das } \\
\text { vértebras e dos úmeros parecem ter sido } \\
\text { intencionais, uma vez que a resistências das } \\
\text { carapaças das conchas podem ter sido } \\
\text { utilizadas para dar estabilidade à fácies que } \\
\text { tendo o aspecto de terra fofa, necessitava de } \\
\text { um elemento mais resistente para auxiliar } \\
\text { na sustentação do corpo. }\end{array}$ \\
\hline $\mathrm{C}$ & $\begin{array}{c}\text { fácies } \\
6 \mathrm{c}\end{array}$ & $\begin{array}{l}\text { Composta predominantemente } \\
\text { por Ostrea sp. e mariscos } \\
\text { triturados dispostos na posição } \\
\text { vertical diferindo das outras } \\
\text { fácies onde as ostras estavam } \\
\text { posicionadas horizontalmente. A } \\
\text { fácies apresenta aspecto solto e } \\
\text { coloração esbranquiçada. }\end{array}$ & $\begin{array}{l}\text { A fácies parece ter sido o resultado de parte } \\
\text { de um montículo que foi cortado para a } \\
\text { retirada do bloco, e provavelmente } \\
\text { integrava outra estrutura arqueológica. }\end{array}$ \\
\hline
\end{tabular}

\section{OS MATERIAIS E SUAS QUALIDADES}

Durante as escavações dos blocos, buscou-se investigar evidências sobre a etapa do ritual que envolve a preparação do terreno para receber o corpo. Para isso, foram categorizados e analisados os seguintes elementos: conteúdo malacológico predominante (representado pelas espécies Anomalocardia brasiliana, Lucina pectinata e Ostrea sp.), marcas de estaca, fogueira e cinzas.

A espécie Anomalocardia brasiliana caracteriza-se por apresentar valvas pequenas e resistentes que, quando concentradas, formam lentes ou camadas que criam volume, asseguram a drenagem e areação do espaço construído, características importantes para a preservação de ossos humanos².

\footnotetext{
2 Essas características foram ressaltadas por Silvia Puccioni em visita às escavações arqueológicas no sambaqui de Amourins.
} 
As conchas (Ostrea sp., Lucina pectinata), cuja incidência é abundante em Amourins, são bivalves com carapaças resistentes e volumosas variando de 6 a $9 \mathrm{~cm}$, ideais para agregar volume, além de garantir a areação e drenagem. Segundo Klokler (2016: 27), podem ter sido consideradas as mais adequadas como material construtivo, o que pareceu ter motivado a seleção destsas carapaças para iniciar a construção do sambaqui.

As valvas de Lucina pectinata foram transformadas em receptáculos para otólitos, pequenas conchas e porções de pequenos peixes, os quais ficaram cuidadosamente protegidos e foram visualizados na fácies $4 \mathrm{a}$, próximo aos ossos humanos. Conforme destacado por Klokler (2016), exemplos semelhantes ocorrem em outros sambaquis como o Jabuticabeira II, sugerindo que, além de serem material construtivo, essas conchas tinham função especial de guardar materiais selecionados assegurando sua integridade.

Klokler (2012) e Gaspar \& Souza (2013) consideram que alguns receptáculos continham comida, remetendo a ideia de oferenda de alimentos para os mortos, como um aspecto importante do ritual funerário dos sambaquieiros. Segundo Klokler (2016), as conchas de Lucina pectinata articuladas formavam uma espécie de "relicário", no sentido que guardavam materiais de expressivo valor simbólico.

\section{MARCAS DE ESTACA}

Os estudos da década de 1980 em Amourins registraram marcas de quatro estacas em formato pontiagudo, com aproximadamente $30-40 \mathrm{~cm}$ de comprimento e 5 a $8 \mathrm{~cm}$ de largura, com uma distância de $50 \mathrm{~cm}$ entre elas. As quatro estavam em linha reta e no mesmo plano da seção da parede da quadrícula, que na época, foram interpretadas como pertencentes a cabanas e o sítio como lugar de moradia (HEREDIA et al.,1982: 182).

$\mathrm{Na}$ atual pesquisa, as marcas de estacas estavam associadas aos sepultamentos, em contexto funerário, tal como já registrado em outros sambaquis como Jabuticabeira II (KLOKLER, 2008) e Sernambetiba (BIANCHINI, 2015). Em Amourins, as marcas apresentaram cerca de $10 \mathrm{~cm}$ de comprimento e $5 \mathrm{~cm}$ de largura, formato cônico e estavam dispostas em posição vertical, semelhante ao exemplo descrito por Klokler \& Gaspar (2013). Foi observado que a marca estava preenchida pelo sedimento da superfície que foi obliterado, demostrando, segundo Bianchini (2015), que a orientação do material de preenchimento permite diferenciar o contato entre a camada que sofreu a intervenção e a marca de estaca.

A presença de marcas de estacas foi identificada tanto na etapa de campo como também durante as escavações dos blocos de sepultamentos. Para efeito de sistematização, as marcas de estacas receberam uma classificação alfa-numérica, sendo E1 e E2 correspondentes às observadas em campo, próximas aos pés do sepultamento A (GASPAR et al., 2013), e E3, E4 e E5, às identificadas na direção do crânio, próximo ao cotovelo direito e próximo aos pés do sepultamento C. Essa última marca de estaca foi identificada durante a etapa de campo (SOUZA et al., 2012).

Nos blocos, as marcas de estacas estavam posicionadas nas extremidades dos corpos, o que sugere que também estavam relacionadas com a delimitação do espaço ritual. No sepultamento C, as estacas E3 e E4 foram colocadas antes das fácies 1c, 2c e 3c, possivelmente tendo sido fincada dentro da camada de cinza para delimitar a área. A marca de estaca E3, visualizada na seção sul do sepultamento C, parece ter sido colocada no momento após a deposição das fácies 1c e 2c, produzindo, durante a sua inserção e após a decomposição da madeira, uma obliteração vertical na fácies $3 \mathrm{c}$, redirecionando o osso de peixe e a valva de Lucina pectinata dispostos na vertical.

Cabe destacar que as marcas de estacas não estavam em contato direto com o cadáver e que, no espaço entre elas e os ossos, havia $15 \mathrm{~cm}$ correspondente a três fácies 
arqueológicas formadas por valvas de mariscos triturados, conchas inteiras e cinzas (Figura 4).

Figura 4 - Marca de estaca E3, na seção Sul do bloco do sepultamento C, o círculo amarelo indica a posição vertical do osso de peixe. $O$ destaque em vermelho indica a dimensão do pacote de sedimentos correspondente a $15 \mathrm{~cm}$, mostrando que a estaca aparentemente não tinha contato direto com o esqueleto (BERREDO, 2018).

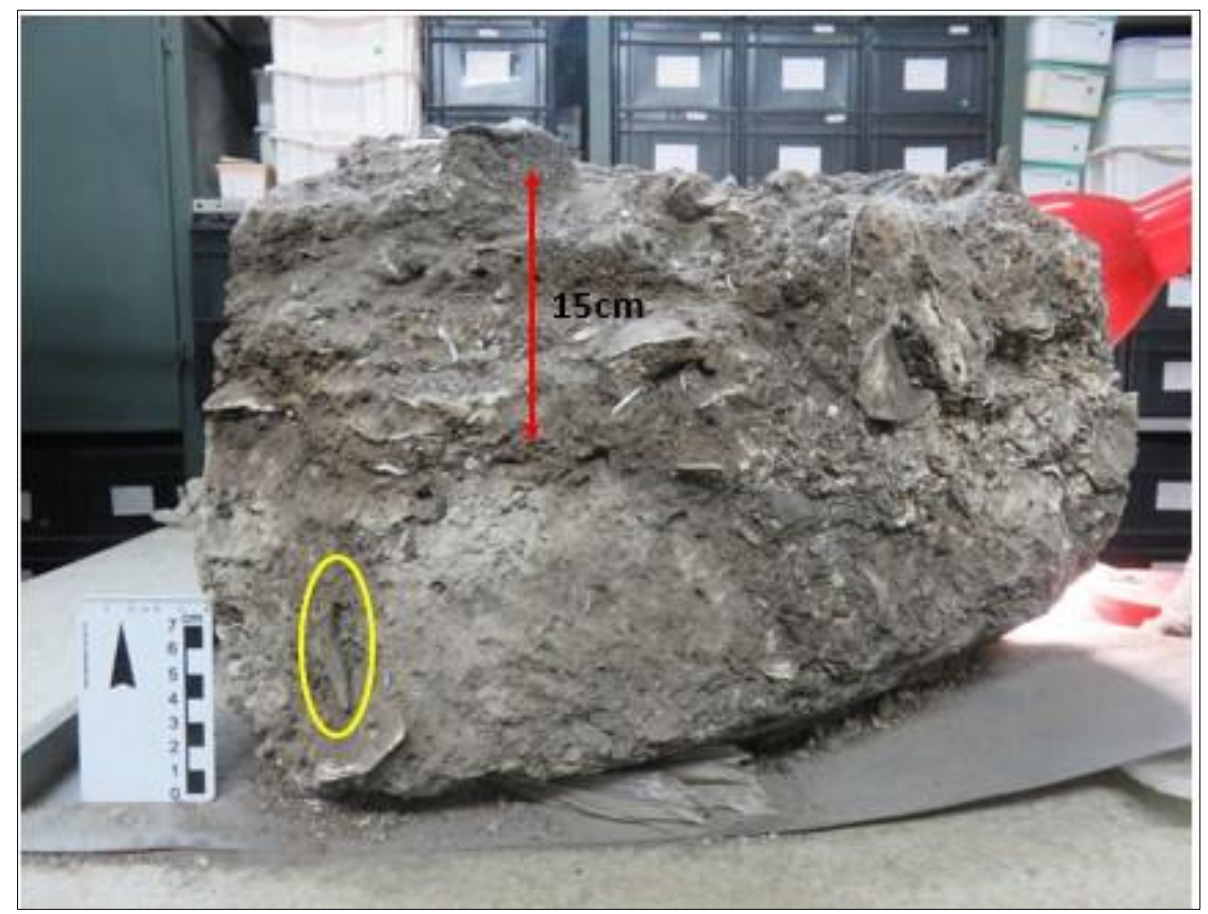

De acordo com Klokler \& Gaspar (2013), a delimitação das marcas de estaca pode ser observada em decorrência de mudanças na inclinação das conchas, que tendem a estar posicionadas em sentido vertical devido a sua acomodação permitindo a entrada da estaca.

Embora os indícios sejam tênues, as observações sugerem a existência de um possível cercado de estacas verticais, ou mesmo um suporte, como um jirau, por exemplo, para as atividades prévias à deposição do corpo, suspeitando-se que podem ter sido usadas para destacar o espaço da cerimônia fúnebre (KLOKLER \& GASPAR, 2013; BIANCHINI, 2015).

\section{FOGUEIRAS E CINZAS}

De acordo com Klokler \& Gaspar (2013) as fogueiras apresentam aspecto lenticular com centro mais espesso e terminações laterais finas. Apresenta estratificação em seu interior com sucessão de lentes escurecidas, numerosos carvões, ossos queimados e cinzas. As autoras ressaltam que a presença de pacote espesso de cinzas indica que fogueiras ficavam ativas por longos períodos de tempo (KLOKLER, 2008; RAUTH, 1969a).

Conforme pesquisas da década de 1980 no sambaqui de Amourins, Heredia et al. (1982) encontraram um sepultamento cujas camadas dispostas acima do esqueleto foram descritas e detalhadas mostrando as diferenças dos elementos encontrados nas proximidades do sepultamento e associadas à volumosa quantidade de ossos de peixes, argila e cinza. Heredia et al. (1982) descreveram a presença de fogueira com forma definida, composta por ossos triturados, cinza e carvões. Além disso, acamada com a 
fogueira apresentou concentração de argila de coloração cinza branca, próximo ao crânio.

Nas escavações a partir de 2010, Gaspar et al. (2013) destacam a existência de uma camada formada por sedimento arenoso, de coloração enegrecida, muito rica em restos de ossos de peixes e carvões, com presença de bolsões de cinzas e extensas fogueiras. $\mathrm{Na}$ seção $30-35 \mathrm{~m}$, a partir da camada funerária, foram investigados traços de fogueira, depósitos de cinzas, carvões e numerosa quantidade de ossos de peixe. Os sinais de queima e as marcas de estaca próximos aos ossos humanos, corroboram a hipótese de que a presença de fogueiras indicaria a proximidade de sepultamentos.

Klokler \& Gaspar (2013: 119) observaram que em Amourins havia fogueiras extensas, estratificadas, presentes logo abaixo de sepultamento, fogueiras com características semelhantes, mas de menor porte, e fogueiras pequenas, compostas por pacote de cinza.

Para o sepultamento A, Souza et al. (2012) observaram nas escavações de campo que o corpo foi depositado logo acima de uma grande fogueira, e as cinzas foram encontradas aderidas aos ossos dos membros inferiores. Além disso, o sepultamento estava inserido em matriz arenosa escura, acompanhada de material queimado e próximo de uma grande fogueira, na qual havia depósitos de cinzas ao lado e abaixo do corpo, além de fogueira associada ao ritual funerário e marcas de estacas próximo ao corpo na altura dos pés e pernas. Em laboratório, foi observado no bloco-testemunho A que as cinzas eram provenientes de intensas fogueiras, provavelmente realizadas em outro local, uma vez que os materiais associados a fácies não apresentaram traços ou coloração decorrente de queima, de modo que as cinzas parecem ter sido depositadas para receber o crânio e parte dos braços, não sendo visualizadas na parte central (costelas e vértebras), o que indica tratamento diferenciado para as partes do corpo.

Para o sepultamento C, Souza et al. (2012) ressaltou que, em $120 \mathrm{~cm}$ de profundidade, foi evidenciada uma estrutura de cinzas de aproximadamente $8 \mathrm{~cm}$ de espessura que cobria parte do corpo (da cabeça até a bacia). Aparece acima do esqueleto uma grande área de fogueira, constituída por material ósseo de peixe, carvão, conchas, misturados em uma matriz escura. Os autores ressaltam ainda que a exposição e documentação dos componentes estratigráficos, sua relação com a estrutura funerária e o esqueleto, permitiram interpretação inicial dos processos construtivos associados a esse sepultamento.

Em laboratório, foi observado no bloco-testemunho $\mathrm{C}$ um pacote de cinzas de $15 \mathrm{~cm}$ de espessura situado na direção do tórax. As características indicam ter sido decorrente de fogueiras realizadas em outro local, uma vez que os materiais associados não apresentaram traços ou coloração decorrente de queima. As cinzas foram consideradas a base da construção do lugar do sepultamento, um marcador do início do ritual.

Cinzas associadas aos sepultamentos também foram evidenciadas no sambaqui Jabuticabeira II, onde Villagran (2010) observou na camada preta - funerária - alta incidência de materiais vegetais, vinculados à queima de plantas. Segundo a autora, a preservação do depósito de cinzas permite inferir que a queima dos seus componentes não teria sido realizada no local, mas em outro espaço, possivelmente próximo ao local do sepultamento. Assim, a deposição das fácies do sambaqui de Jabuticabeira II representa a existência de momentos distintos de remobilização de elementos desde a fogueira até o local do morto, onde o transporte de materiais não necessariamente envolveria longas distâncias e as fogueiras poderiam estar localizadas em áreas próximas aos montículos nos quais acontece o ritual funerário. 


\section{CONSTRUINDO A CENA FÚNEBRE}

A pesquisa nos blocos-testemunhos de Amourins revelou a escolha de materiais utilizados na preparação do terreno para os rituais funerários do grupo. É importante destacar que tais escolhas de materiais para compor depósitos relacionados com rituais podem ter sido guiadas por atribuição de propriedades simbólicas difíceis de serem estabelecidas, mas que cabe à arqueologia investigar.

De acordo com os resultados obtidos, foram identificadas sucessivas deposições intencionais de materiais selecionados durante as atividades que antecedem a deposição dos corpos no ritual funerário realizado em Amourins.

Para o bloco-testemunho A, o preparo do local para receber o corpo começou com a deposição de uma fácies de conchas duras e resistentes, formando uma camada firme composta de bioclastos grandes. Tal fácies permitiu o levantamento do solo, formando uma superfície permeável às águas de chuva e sua circulação, parecendo ter funcionado como uma forma de separação entre o solo argiloso e úmido, e, as fácies subsequentes.

Em seguida, aparece um depósito sedimentar composto de ossos de peixes pequenos que foram dispostos de forma horizontal e estratificada interseccionadas por lentes de carvão. Notou-se que esta fácies parece ter sido interrompida intencionalmente por uma lente de cinzas que corresponderia a um outro montículo formado no sítio.

Acima, observou-se a fácies de cinza, compacta e firme, que estava em contato com os membros superiores, especialmente úmeros e fêmures. Depois, foi observada a presença de outra fácies concentrada na área do tórax e pelve, indicando escolha diferenciada de depósitos sedimentares para essa parte do corpo. Além disso, foi encontrada uma concha de Lucina pectinata que continha outra concha menor e de mesma espécie em seu interior, além de outras contendo ossos de peixes pequenos e vértebras de peixes grandes, compondo oferendas funerárias. A última fácies observada foi composta por conchas fechadas de Lucina pectinata e Ostrea sp. ordenadas de modo a formar uma espécie de receptáculo para o crânio (Figura 5).

Figura 5 - Bloco-testemunho A contendo crânio com a fácies estratigráficas, onde aparece uma sequência de conchas de Lucina pectinata formando receptáculo para cabeça e também formando a fácies de início de construção do bloco.

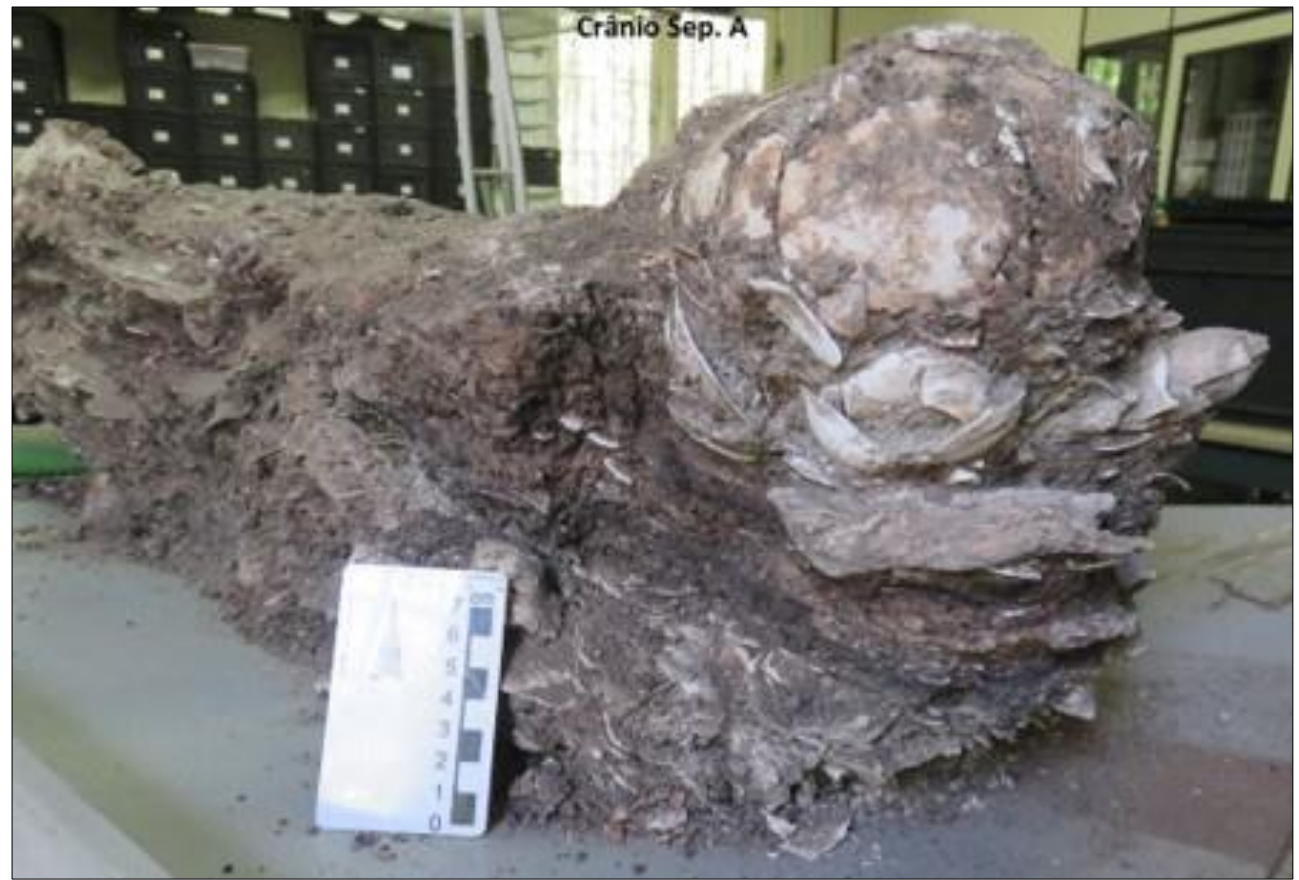


Para o bloco-testemunho A, cabe destacar as características dos depósitos de cinza que foram visualizados concentrados abaixo da porção do tórax que contém as partes vitais do corpo, além de músculos, cartilagem e ligamentos. Tal disposição não foi observada para os membros inferiores, levando a considerar que partes do corpo sem órgãos vitais à sobrevivência humana poderiam ser tratadas de maneira distinta.

No caso do sepultamento $C$, as atividades tiveram início com a deposição de uma camada de cinzas com um pacote sedimentar espesso de $15 \mathrm{~cm}$ que deram a base para a colocação do corpo. Essa fácies foi interrompida por outra composta por pequenos ossos de peixe e mariscos triturados que parecem ter sido resultado que outro montículo preexistente. Em seguida, foi evidenciada a fácies formada por ossos de peixe, areia e poucas conchas de Lucina pectinata, sendo interrompida por duas estacas verticais, dispostas nas seções leste e sul, que deslocou parte dos elementos dessa fácies (Figura 6).

Figura 6 - Seção Leste do bloco-testemunho C mostrando o espesso pacote de cinza iniciando a construção; a fácies que interrompe o depósito de cinzas, resultado possivelmente de outro montículo; a marca de estaca com os elementos conchíferos dispostos na direção vertical.

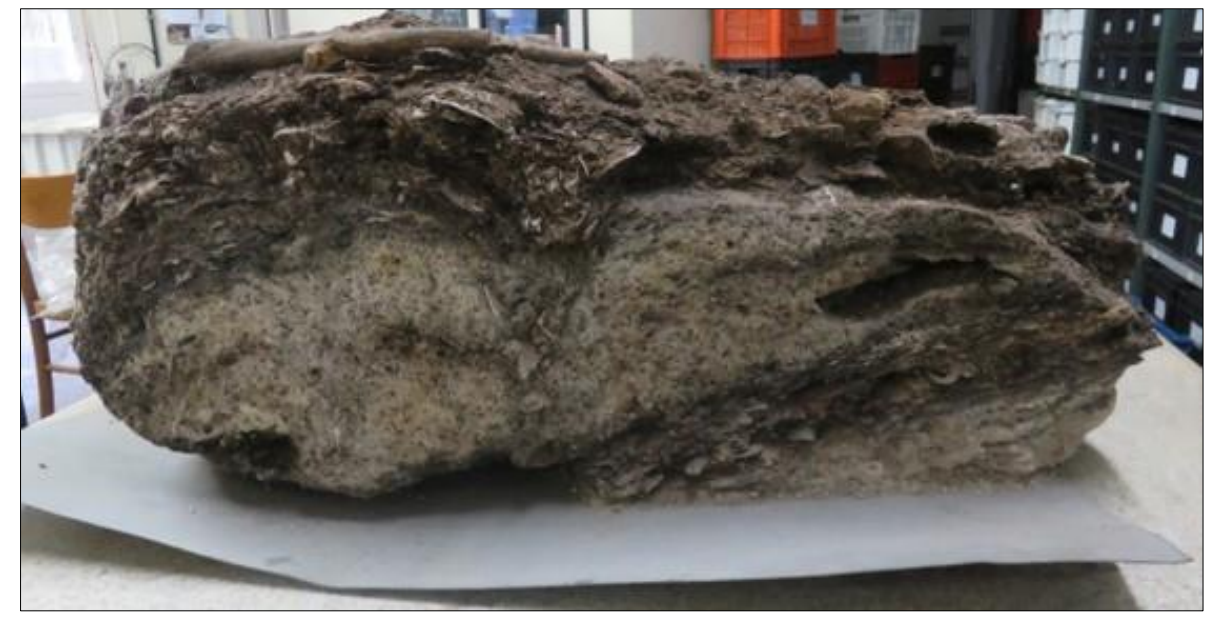

Ainda se tratando do bloco-testemunho C, acima da fácies com as marcas de estaca, foram depositados numerosos exemplares de conchas de Lucina pectinata que possuem características que deram aspecto firme e robusto à fácies. Logo acima, foi observado sedimento marrom escuro, solto e com aspecto de "terra fofa", composto por ossos de peixes, mariscos triturados e conchas inteiras que estavam em contato direto com os ossos humanos. Nesta fácies notou-se a disposição de conchas de Lucina pectinata abaixo das vértebras e dos úmeros que parecem ter sido dispostas de forma intencional, uma vez que a resistência das carapaças das conchas pode ter sido utilizada para dar estabilidade à camada. A última fácies estava disposta na posição vertical, formada por conchas e mariscos triturados, sugerindo ter tido pouca relação com a preparação do terreno para receber o sepultamento. A análise estratigráfica considerou-a pertencente a outro montículo.

Conforme já mencionado por Souza et al. (2012), foi evidenciada no sepultamento $\mathrm{C}$ uma estrutura de cinzas com cerca de $0,8 \mathrm{~m}$ de espessura que cobria parte do corpo correspondente à área que vai do crânio à pelve, sendo considerada uma grande área de fogo, que também era composta por material ósseo, carvões e conchas.

O espesso depósito de cinzas evidenciado na escavação em campo e em laboratório do bloco-testemunho $\mathrm{C}$ indica a relação tempo/cuidado que foram designados a grupos de pessoas ou indivíduos como parte das atividades a serem realizadas no ritual. As fogueiras parecem ter sido acesas com a intenção da utilização dos fragmentos de carvão 
e cinzas em diferentes etapas da construção da cena fúnebre, onde as cinzas podem ter sido utilizadas como marcadores do início e finalização do ritual funerário.

A quantidade e diversidade de materiais encontrados nos blocos leva às atividades de preparação do terreno para receber o corpo que parecem ter envolvido grupo significativo de pessoas responsáveis pela realização de afazeres distintos. Os membros desse grupo desempenhariam diferentes funções, como a seleção das conchas mais duras para serem colocadas na sustentação da construção, enquanto outros seriam responsáveis pela seleção de madeira apropriada para a queima.

As valvas de moluscos parecem ter sido escolhidas para acompanhar o cadáver, já os exemplares de Lucina pectinata serviriam de receptáculo para outras conchas e ossos de peixe articulados (Figura 7), proteção de partes do esqueleto, adorno para a cabeça, joelhos, e, em alguns casos, para iniciar e finalizar o sepultamento do corpo.

Figura 7 - a) Receptáculo de Lucina pectinata com outra concha menor da mesma espécie em seu interior. b) Valva de Lucina pectinata contendo ossos articulados de peixe de pequeno porte. c) Valva de Lucina pectinata com vértebra de Tunnus sp. em seu interior.

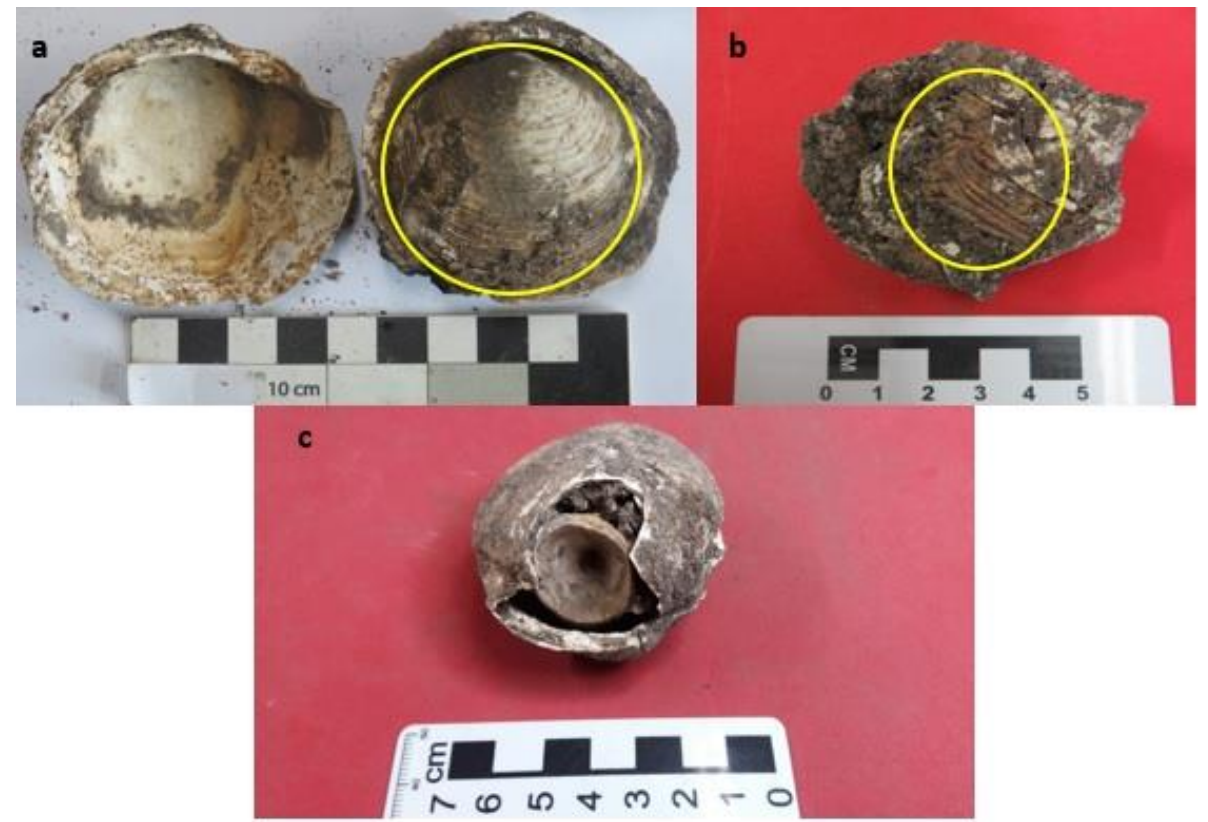

Peixes pequenos foram escolhidos para compor a estrutura construtiva. Já os peixes maiores, como atum e tubarões, foram colocados próximos à cabeça e aos pés como oferendas. As estacas parecem ter sido usadas para delimitar ou sustentar a construção do lugar do morto, servindo como apoio para a criação de uma possível estrutura para receber os diferentes materiais e o próprio cadáver.

Corroborando a proposta de Klokler \& Gaspar (2013), a partir das atividades empreendidas pelos pescadores-coletores, é possível considerar que o ritual foi formatado com materiais escolhidos e coletados especialmente para a preparação do terreno que receberia o corpo, constituindo uma cerimônia pública que reuniu grupos numerosos, tal como vem sendo proposto por Fish et al. (2000), Klokler (2008) e Gaspar et al. (2013).

Para avançar na interpretação do ritual funerário e especialmente refletir sobre espaço ritual e arquitetura sambaquieira, analisou-se a cena fúnebre retratada por Marechal Rondon em 1916 (QUEIROZ, 2017). Não está sendo proposta vinculação cultural entre esse grupo tribal e os construtores de Amourins, mas a imagem está sendo usada com a intenção de considerar que muito provavelmente, no ritual funerário 
realizado em Amourins, participassem muitas pessoas. Vale ressaltar que os estudos em outro sambaqui, como Sernambetiba (BIANCHINI, 2015; ESTANEK, 2016; ÁVILA, 2018), e outras análises realizadas no próprio Amourins (CARDOSO, 2013; BERREDO, 2018; SOUZA-PINTO, 2018), indicam que os sepultamentos se desenvolveram no topo dos cemitérios, nas suas porções já erigidas, muito provavelmente para assegurar ampla visibilidade ao rito funerário.

A foto obtida pelo Marechal Rondon fornece uma dimensão da quantidade e diversidade de atividades que integram um ritual e o grande número de participantes da cena fúnebre. O corpo ocupa posição central, colocado no chão em que é molhado com líquido vertido de um grande vasilhame cerâmico. Algumas pessoas aparecem dançando, ditando o ritmo da cerimônia com suas maracas, e os mais distantes acompanham o ritual com olhares atentos, enquanto outro personagem trajando um manto e portando um cajado, permanece em frente ao corpo e parece dirigir a cena.

Inspirada no fotograma feito por Rondon e levando em consideração a sequência de atividades identificadas na análise dos blocos, foi elaborada uma "interpretação gráfica” por Henrique Vences, na qual vê-se a possível forma ritual dos sambaquieiros que envolviam uma numerosa quantidade de pessoas e também utilização de elementos ligados ao cotidiano (Figura 8).

Figura 8 - À esquerda está a cena de ritual e festa Bororo, danças, pesca e o corpo central na cerimônia funerária (QUEIROZ, 2017). À direita, a interpretação gráfica da cena ritual do sambaqui de Amourins mostra o corpo como elemento central e as pessoas reunidas a sua volta para cuidar e homenagear o morto. No topo estão três canoas representando a atividade de pesca; próximo à canoa da margem do rio, outros pescadores aparecem em terra trazendo consigo o pescado a ser utilizado na construção do lugar do morto ou para oferendas alimentares; à esquerda há está representada a coleta da cinza de fogueira, assim como a atividade de coleta, seleção e maceração das conchas; à direita outras pessoas transportam lenha para a manutenção da fogueira (desenho: Henrique Vences).
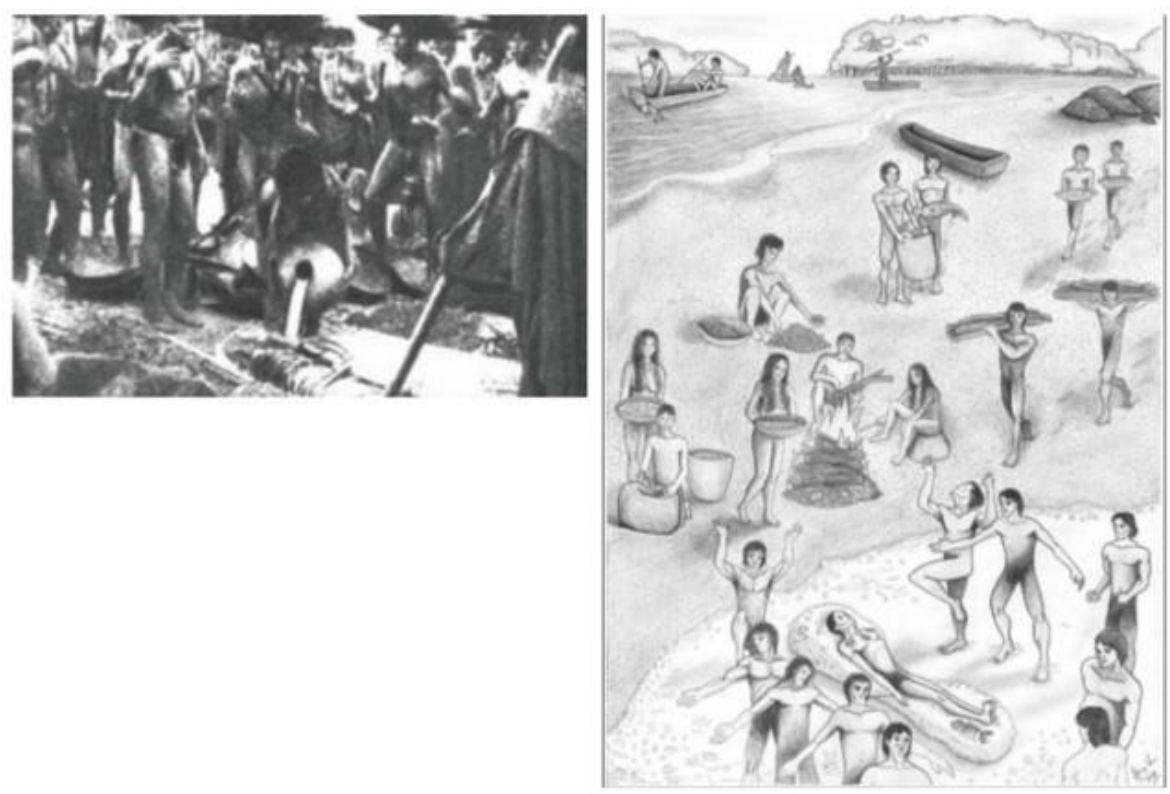

A morte para os sambaquieiros se tratava de cerimônia com alta visibilidade e o ritual funerário implicava a realização de diversas atividades envolvendo o grupo de pescadores-coletores e tendo o cadáver a posição central. Os condutores do rito atualizavam o programa funerário realizando atividades iniciais de escolha, seleção e preparação dos materiais para serem depositados com a intenção de formatar a cena fúnebre. É possível supor que a participação de muitos sambaquieros deve ter sido 
importante para a construção da dramaticidade do evento, mas principalmente ressaltando a visibilidade do sambaqui.

\section{CONCLUSÃO}

Os resultados obtidos durante a pesquisa indicam que o ritual funerário no sambaqui de Amourins incluía uma série de atividades que antecediam a deposição do corpo e que, muito provavelmente, envolvia a seleção de materiais do cotidiano.

As fácies arqueológicas de dois blocos-testemunhos foram descritas, analisadas e interpretadas de modo a verificar quais tipos de elementos cotidianos estavam sendo selecionados pelos construtores do sambaqui de Amourins para formatar o terreno que receberia o corpo. Dentre os elementos destacados estão as conchas, ossos de peixe e cinzas, que eram ressignificados ao integrarem o ritual funerário.

A morte de um membro do grupo era um momento de intensa sociabilidade, em que havia circulação de informações e que hábitos e costumes eram compartilhados, mantidos e atualizados conforme as condições sociais preponderantes em cada período e região. Para compor a cena fúnebre, foram realizadas uma série de atividades bem conduzidas e arquitetadas, sugerindo promover a interação de um grupo comprometido com a organização do ritual funerário e dos demais participantes. 


\section{REFERÊNCIAS BIBLIOGRÁFICAS}

ÁVILA, André. 2018. Da paisagem aos ritos e festins funerários: análise antracológica do sambaqui de Sernambetiba (Recôncavo da Baía de Guanabara, RJ). Dissertação de Mestrado. Rio de Janeiro, Universidade Federal do Rio de Janeiro.

BELL, Catherine. 1997. Ritual: Perspectives and Dimensions. New York, Oxford University Press. 368pp.

BELTRÃO, Maria. 1978. Pré-História do Estado do Rio de Janeiro. Rio de Janeiro, Forense Universitária, $276 \mathrm{pp}$.

BELTRÃO, Maria; HEREDIA, Osvaldo; RABELLO \& Angela; PEREZ, Roneds. 1981/82. Pesquisas arqueológicas no sambaqui de Sernambetiba. Arquivo do Museu de História Natural, Belo Horizonte, VI/VII:145-155.

BERREDO, Ana Luiza. 2018. Ritual funerário no sambaqui de Amourins: atividades de preparação do terreno para receber o corpo. Dissertação de Mestrado. Rio de Janeiro, Universidade Federal do Rio de Janeiro. 187pp.

BIANCHINI, Gina F. 2008. Fogo e Paisagem: evidências de práticas rituais e construção do ambiente a partir da análise antracológica de um sambaqui no litoral sul de Santa Catarina. Dissertação de Mestrado. Rio de Janeiro, Universidade Federal do Rio de Janeiro. 250pp.

BIANCHINI, Gina F. 2015. Por entre corpos e conchas: prática social e arquitetura de um sambaqui. Tese de Doutorado. Rio de Janeiro, Universidade Federal do Rio de Janeiro. 199pp.

CARDOSO, Lilian. 2013. Além das Conchas: Análise Zooarqueológica do Sambaqui de Amourins. Dissertação de Mestrado. Rio de Janeiro, Universidade Federal do Rio de Janeiro. 176pp.

DEBLASIS, Paula; KNEIP, Andreas; SCHEEL-YBERT, Rita; GIANNINI, Paulo \& GASPAR, Maria D. 2007. Sambaquis e paisagem: Dinâmica natural e arqueologia regional no litoral do sul do Brasil. Arqueología Sul-Americana, 3:29-61.

ESTANEK, Angélica. 2016. Preparativos funerários no Sernambetiba - Sambaqui vida e morte. Tese de Doutorado. Museu Nacional, Universidade Federal do Rio de Janeiro, Rio de Janeiro. $227 \mathrm{pp}$.

FISH, Suzanne; DEBLASIS, Paulo; GASPAR, Maria Dulce; FISH, Paul. 2000. Eventos incrementais na construção de sambaquis, litoral sul do Estado de Santa Catarina. Revista do Museu de Arqueologia e Etnologia, n. 10, p. 69-87.

GASPAR, Maria D.1991. Aspectos da Organização de um grupo de pescadores, coletores e caçadores: região compreendida entre a Ilha Grande e o Delta do Paraíba do Sul, Estado do Rio de Janeiro. Tese de Doutorado. São Paulo. Universidade de São Paulo. 362pp.

GASPAR, Maria D. 2000. Sambaqui: arqueologia do litoral brasileiro. Rio de Janeiro, Jorge Zahar, 92pp.

GASPAR, Maria D.; KLOKLER, Daniela; SCHEEL-YBERT, Rita \& BIANCHINI, Gina F. 2013. Sambaqui de Amourins: mesmo sítio, perspectivas diferentes. Arqueologia de um sambaqui 30 anos depois. Revista do Museu de Antropologia de Córdoba, 6: 7-20.

GASPAR, Maria D. \& Souza, Sheila M. 2013. Pesquisa de campo em sambaquis: introdução. In: Madu Gaspar, Sheila Mendonça de Souza. (Org.). Abordagens Estratégicas em Sambaquis. 1ed.Erechum: Habilis, 2013, v. 1, p. 15-32.

HEREDIA, Osvaldo \& BELTRÃO, Maria. 1980. Mariscadores e pescadores pré-históricos do litoral centro-sul brasileiro. In: SCHMITZ, P. I. Estudos de arqueologia e pré-história brasileira em memória de Alfredo Teodoro Rusins. Rio de Janeiro, IAP, pp.101-119.

HEREDIA, Osvaldo.; BELTRÃO, Maria; OlIVEIRA, Maria D. \& GATTI, Marcelo. 1982. Pesquisas arqueológicas no sambaqui do Amourins. Arquivos do Museu de História Natural, $7: 175-188$ 
KLOKLER, Daniela. 2008. Food for Body and Soul: Mortuary Ritual in Shell Mounds (Laguna Brazil). Tese de Doutorado. Arizona, College the University of Arizona. 369pp.

KLOKLER, Daniela. 2012. Consumo ritual, consumo no ritual: festins funerários e sambaquis. Revista Habitus, Goiânia, PUC Goiás, v. 10, n. 1: 83-104.

KLOKLER, Daniela. 2016. Animal para toda obra: fauna ritual em sambaquis. Revista Habitus, Goiânia, 14(1):21-34.

KLOKLER, Daniela. 2016. Otólitos, para que te quero? Revista Habitus, Goiânia, v. 14, n.1, p. 21-34, jan./jun.

KLOKLER, Daniela \& GASPAR, Maria D. 2013. Há uma estrutura funerária em meu sambaqui..., Esse sambaqui é uma estrutura funerária! In: GASPAR M. D.; SOUZA. S. M. (Org.). Abordagens estratégicas em sambaquis. Erechim/RS, Habilis. pp.109-125.

KNEIP, Lina \& MACHADO, Lilia. 1993. Os ritos funerários das populações pré-históricas de Saquarema, RJ: sambaquis da Beirada, Moa e Pontinha. Documento de Trabalho, Série Arqueologia, Rio de Janeiro, 1:1-76.

MACHADO, Lilia. 1995. Tendências à continuidade e mudanças em Ritos Funerários. In: BELTRÃO, M. C. Arqueologia do Estado do Rio de Janeiro. Niterói: Arquivo Público do Estado do Rio de Janeiro, pp.111-118.

MAGALHÃES, Artur; BERREDO, Ana Luiza; e GASPAR, Madu. 2018. De volta ao passado: a aplicação da fotogrametria para registro arqueológico 3D. Revista de Arqueologia da SAB. Volume 31. Pp. 185-207.

MELLO, Elisa \& SOUZA, Alfredo. 1977. O Sambaqui de Saracuruna. Nheengatu, Instituto Superior de Cultura Brasileira, Rio de Janeiro, 7(1). Pp. 43-58.

MENDONÇA DE SOUZA, Sheila; MENDONÇA DE SOUZA, Alfredo. 1983. Tentativa de interpretação paleoecológica do sambaqui do rio das Pedrinhas-Magé-RJ. Instituto Superior de Cultura Brasileira, Rio de Janeiro.

PAZ, Roneds A. 1999. Arqueologia da Baía de Guanabara: estudo dos sambaquis do município de Guapimirim. Tese de Doutorado. Universidade de São Paulo, São Paulo, 220 pp.

PEARSON, Michael. 2002. Archaeology of Death and Burial. Texas, M University Press, 250 pp.

PLENS, Cláudia, 2007. Sítio Moraes, uma biografia não autorizada: análise do processo de formação de um sambaqui fluvial. 2007. Tese de doutorado. Universidade de São Paulo, São Paulo.

QUEIROZ, Christina. 2017. Bororo na tela. Revista Pesquisa FAPESP. Série Humanidades, São Paulo, 255:80-85.

RAMOS, Renato R.C.; GARCINDO, Lucas B. \& BIANCHINI, Gina F. 2013. Sambaquis: análise e registro estratigráfico através do uso de fotomosaicos. In: GASPAR M. D.; SOUZA. S. M. (Org.), Abordagens Estratégicas em Sambaquis. Erechim, Habilis. pp.75- 87.

RAUTH, José W. 1969a. Nota prévia sobre as escavações do Rio São João. Publicações avulsas do Museu Paraense Emilio Goeldi, 10, 75-94.

SILVA, Sérgio. 2005. Arqueologia das práticas mortuárias em sítios pré-históricos do litoral do Estado de São Paulo. Tese de doutorado. Universidade de São Paulo, São Paulo.

SOUZA, Sheila M. 2003. Arqueologia de funerais: quando os mortos esclarecem os (arqueólogos) vivos. In: Congresso Da Sociedade De Arqueologia, vol. 12, 2003, São Paulo. Anais...São Paulo: Sociedade de Arqueologia Brasileira.

SOUZA, Sheila M.; LIRYO, Andersen; BIANCHINI, Gina F. \& GASPAR, M.D. 2012. Sambaqui do Amourins: Mortos para mounds? Revista de Arqueologia da SAB. 25(2): 84-103. 
SOUZA, Sheila M.; WESOLOWSKI, Verônica; LESSA, Andrea; RODRIGUES-CARVALHO, Claudia, 2013. Identificar e Escavar Lugares de Deposição de Mortos. In: GASPAR, M.D.; MENDONÇA DE SOUZA, S.M. Abordagens Estratégicas em Sambaquis. Erechim/RS. Habilis, $1^{\text {a }}$ edição. v. 1, p. 127-154.

SOUZA, Sheila M. \& RODRIGUES-CARVALHO, Claudia. 2013. Ossos no chão: para uma abordagem dos remanescentes humanos em campo. Boletim do Museu Paraense Emílio Goeldi, Seção: Ciências Humanas, 8(3): 551-566.

SOUZA-PINTO, Natacha R. 2018. Cultura e Ritual no Sambaqui Amourins: uma história através de macrovestígios vegetais. Dissertação de Mestrado. Rio de Janeiro, Universidade Federal do Rio de Janeiro.

VILLAGRÁN, Ximena S. 2010. Geoarqueologia de um Sambaqui Monumental - estratigrafias que falam. São Paulo, Annablume, Fapesp, 213pp. 